\title{
Participatory process for mapping socio-environmental determinants of health by community agents: Contributions to urban management
} and planning

Processo participativo para o mapeamento de determinantes socioambientais de saúde por agentes comunitárias: contribuições para a gestão e o planejamento urbano

Renata Ferraz de Toledo ${ }^{1}$ (D) Ana Paula Koury ${ }^{1}$ (D), Carolina Monteiro de Carvalho ${ }^{2}$ (D) Francisco Nilson Paiva dos Santos $^{3}$ (D)

\section{A B S T RAC T}

Studies about socio-environmental determinants are recognized as important to better understand the factors that influence health and quality of life, and how they operate to generate inequalities. This article reports the mapping of socio-environmental determinants of health, carried out by community health agents from the community of Paraisópolis, the second-largest slum in the city of São Paulo (state of São Paulo), seeking to analyze potential contributions of this participatory process to urban management and planning. As part of an action research study and following the stages of Paulo Freire's Research Itinerary (Culture Circles), the mapping was carried out by integrating the Talking Map technique with Geographic Information Systems (GIS), in what has been called Participatory GIS or Geographic Information Systems with Social Participation (PGIS). Positive aspects were recognized and addressed by community agents, as well as several situations of socio-environmental vulnerability as a result of the agglomerated nature of the place, directly related to urban management and planning needs. This shows that, through a participatory mapping process, citizens cannot only better identify, but also more effectively communicate their needs and qualify intervention strategies in the territory. Therefore, it is possible to address the residents' priorities more representatively, especially in places where traditionally marginalized social groups live. And also, community health agents, who play a central role in this research process because they live and work in the same place, are fundamental to boost, mobilize, and support the complex aspects involved, both in Primary Health Care, as well as in urban management and planning.

Keywords: primary health care; social determinants of health; Paraisópolis; action research; geographic information systems with social participation.

\section{R E S U M 0}

Estudos sobre determinantes socioambientais são reconhecidos como importantes para melhor compreender fatores que influenciam na saúde e qualidade de vida e como eles podem operar na geração de iniquidades. Este artigo relata o mapeamento de determinantes socioambientais de saúde realizado por agentes comunitárias de Paraisópolis, a segunda maior favela da cidade de São Paulo (SP), buscando analisar possíveis contribuições desse processo participativo para a gestão e o planejamento urbano. Como parte de uma pesquisa-ação e seguindo etapas do itinerário de pesquisa de Paulo Freire (Círculos de Cultura), o mapeamento foi realizado integrando a técnica do mapa-falante com sistemas de informação geográfica (SIG), no que vem sendo chamado de SIG participativo ou SIG com participação social. Foram reconhecidos pelas agentes comunitárias, tornando-se objetos de reflexão, aspectos positivos, bem como diversas situações de vulnerabilidade socioambiental do aglomerado diretamente relacionadas às demandas de gestão e planejamento urbano. Isso evidencia, portanto, que, por meio desse processo de mapeamento participativo, os cidadãos podem não apenas melhor identificar, como também comunicar mais eficazmente suas necessidades e qualificar estratégias de intervenção no território, atendendo de modo mais representativo às prioridades dos moradores, especialmente nas localidades em que os grupos sociais tradicionalmente marginalizados residem. Ainda, no caso de agentes comunitárias de saúde, as participantes centrais desta pesquisa, por morarem no local onde atuam elas são essenciais para impulsionar, mobilizar e apoiar as engrenagens complexas tanto da Atenção Básica em Saúde como da gestão e do planejamento urbano.

Palavras-chave: atenção básica em saúde; determinantes sociais da saúde; Paraisópolis; pesquisa-ação; sistemas de informação geográfica com participação social.

\footnotetext{
${ }^{1}$ Universidade São Judas Tadeu - São Paulo (SP), Brazil.

${ }^{2}$ Universidade de São Paulo - São Paulo (SP), Brazil.

${ }^{3}$ Hospital Albert Einstein - São Paulo (SP), Brazil.

Correspondence address: Renata Ferraz de Toledo - Pesquisa e Pós-Graduação Stricto Sensu, Universidade São Judas Tadeu - Rua Taquari, 546, 2o Andar, Bloco C - CEP: 03166-000 - São Paulo (SP), Brazil. E-mail: renata.toledo@saojudas.br
}

Conflicts of interest: the authors declare no conflicts of interest.

Funding: none.

Received on: 01/20/2021. Accepted on: 07/28/2021.

https://doi.org/10.5327/Z217694781035

This is an open access article distributed under the terms of the Creative Commons license. 


\section{Introduction}

The socio-environmental determinants of health, that is, the various individual, social, and macro-structural factors that condition and determine people's health and quality of life (CSDH, 2008; Sobral and Freitas, 2010), were recognized and mapped by community health agents (CHAs) in the territory covered by Paraisópolis II Basic Health Unit (BHU), in the community of Paraisópolis, city of São Paulo (state of São Paulo). The talking map construction technique was used in association with participatory mapping, applied in an action research process (Toledo and Giatti, 2015), and the stages of the Culture Circles, part of Paulo Freire's Research Itinerary (Freire, 2019), were followed. Participatory mapping is a set of approaches and techniques that combines modern cartography tools with participatory methods to record and represent the spatial knowledge of local communities and, therefore, bring about social change (Cochrane and Corbett, 2020; Mapping For Rights, 2020), by identifying priorities and necessary interventions (Freitas et al., 2020). This method is part of a Participatory Geographic Information System (PGIS).

Together with other health professionals, CHAs are part of Family Health Strategy (FHS) teams that carry out individual and collective actions, especially in education and health promotion and disease prevention, at people's homes or in a community context, in a certain area attached to a reference $\mathrm{BHU}$, according to the guidelines for Preventive Health and Primary Health Care of the Brazilian Unified Health System (Sistema Unico de Saúde, SUS). As they also live in the area where they professionally work, CHAs are immersed in the local context. Therefore, it is expected that they can more easily recognize the socio-environmental determinants that influence the health of the community and interact with the population. They also give voice to their potential claims, since very asymmetric power relations tend to hinder intercommunication between health professionals and users. Several studies even show bonds and affection between CHAs and the community, with positive implications for the territory (Bezerra and Feitosa, 2018; Brasil, 2018; Faria and Paiva, 2020; Silva et al., 2020).

In the specific setting of this research, Paraisópolis community, located in Vila Andrade, Morumbi neighborhood, in the southern zone of the city of São Paulo (SP), several problems directly and indirectly impact the health of the local population: absent or poor basic sanitation, unhealthy housing, presence of disease vector animals, among others that are associated with incomplete urbanization projects, especially due to political issues involving administration changes that intensify degradation of the territory, situations of vulnerability, and social exclusion (Maziviero and Silva, 2018).

Maps of the territory covered by Paraisópolis II BHU were then produced by $\mathrm{CHAs}$ representing socio-environmental determinants with positive and negative influence on the health of local residents, by integrating the Talking Map technique with Geographic Information Systems (GIS), in what has been called Participatory GIS or Geographic Information Systems with Social Participation (PGIS) (Carvalho and
Giatti, 2018). PGIS represents the spatial knowledge of local people by applying geospatial technologies that facilitate social engagement and participation in decision-making processes and support communication and advocacy of the community's interests. Therefore, they have great power to produce social changes (McCall, 2004).

Some studies have shown contributions of geoprocessing in the health area, especially in Primary Care, as evidenced in the systematic review conducted by Salinas Rebolledo et al. (2018), given the growing demand for interdisciplinary and intersectoral actions focused on the socio-environmental determinants of health. The authors identified benefits from the use of this technology, for example, in estimating the health professionals' commute time in the territory, in spatially quantifying access to health services and programs, and in identifying environmental conditions and situations of inequality, among other aspects that make decision-making more efficient. On the other hand, the authors also mention that the publications analyzed do not highlight the potential contributions of geoprocessing to motivate the work of health professionals or even engage the community.

Thus, geoprocessing offers clear benefits for the health area, especially in Primary Care, as well as for urban planning. Many papers have explored the correlations between health and environmental conditions, resorting to geoprocessing tools. In this field, contributions that show this relationship stand out, mainly in vulnerable territories (Arcoverde et al., 2018; Almeida et al., 2020). In urban planning, the papers explore the new information technologies applied to the participatory mapping of urban vulnerabilities (Kahila-Tani et al., 2019; Abranches, 2020). The possible contributions of this Health Care level (Maman et al., 2009; Goldstein et al., 2013; Fornace et al., 2018; Arouca et al., 2019; Magalhães, 2021; Moraes et al., 2021), especially by the performance of CHAs, in the management and planning of urban spaces have been less explored by the literature.

Therefore, the question is how the mapping process of socio-environmental determinants of health, when carried out in a participatory manner and by Paraisópolis CHAs, can contribute to urban management and planning.

Although this research provides results referring to the specific territory of Paraisópolis, São Paulo, we believe in the replicability potential of the methodology reported herein, as well as in its relevance to improve studies and practices in this interdisciplinary field, in an interface between health, environment, and urbanism.

Therefore, this article aims at analyzing potential contributions of the participatory process of mapping socio-environmental determinants of health to urban management and planning, when carried out by community agents.

\section{Socio-environmental determinants of health}

Associations between the way people live and eat, the environment they occupy, etc., and health are not recent; they date back to ancient times and, for centuries, philosophers have made assumptions trying 
to understand the factors that influenced human health and the process of illness. In the $19^{\text {th }}$ century, John Snow's studies on cholera, which mapped cases of the disease in a London neighborhood, are noteworthy, as well as the social medicine movement, more intense during that time in Germany, France, and England, where socio-environmental aspects were timidly considered in the conception of health. However, later in the same century, with the discovery of microscopic agents that spread diseases, the focus was shifted to controlling these pathogens, inaugurating a period of strong biological determinism (Sobral and Freitas, 2010).

During the $20^{\text {th }}$ century, the socio-environmental factors were present in the reflections of various events in the health area and the documents resulting thereof. Philippi Junior et al. (2014) consider the creation of the World Health Organization (WHO) in 1946 as a significant milestone in the constitution of environmental systems, as well as the first General Health Assembly in 1948, where health is defined as more than the absence of disease, a state of complete physical, mental, and social well-being. Other documents gradually incorporated this view of comprehensive health throughout the century and expanded the understanding of its multi-causality, as identified in the Declaration of Alma-Ata, resulting from the International Conference on Primary Health Care, held in 1978, and in the $8^{\text {th }}$ National Health Conference, held in Brazil in 1986, an important landmark of Brazilian sanitary practices. Additionally, it is possible to mention the Health Promotion Movement, which highlights, among other aspects, the importance of environments that are conducive to health and healthy public policies for people to live healthy lives; or even in the Organic Health Law itself, known as the SUS Law (Brazilian Federal Law 8,080, of September $\left.19^{\text {th }}, 1990\right)$.

However, it can be asserted that it was only recently, since the creation of the World Commission on Social Determinants of Health (CSDH) by the WHO in 2005, that the focus has shifted to better understanding which factors can influence health and how they operate in generating health inequalities $(\mathrm{CSDH}, 2008)$, especially among the most vulnerable, that is, those with greater difficulty or limited capacity to react to certain risks (Carmo and Guizardi, 2018). The health of individuals and social groups is now recognized as resulting from individual, social, and macro-structural determinants, that is, the different situations in which people are born, grow, work, live, and age throughout their lives (CSDH, 2008; Akerman et al., 2011).

This layered organization of the social determinants of health was proposed by the Dahlgren and Whitehead Model, which considers the following as individual determinants: hereditary characteristics, gender, age, and lifestyle; as social determinants: the various living and working conditions, such as access to and quality of housing, food, sanitation, education and health services, among others; and, as macro-structural determinants: the general economic, social, cultural, environmental, and health public policies. This model also highlights the interdependence between these layers and determinants, and that actions aimed at addressing situations of inequalities must be taken simultaneously at the individuals' proximal level, at the intermediate level, and at the distal level, to favor adequate conditions and allow healthy choices (Sobral and Freitas, 2010).

Research studies relating the various socio-environmental factors with human health have been conducted with different approaches and in different contexts. When investigating the aged population, Cassol (2012) recognized three scenarios of how environmental determinants influence the health-disease process: the first one relating cardiovascular and neoplastic diseases both to genetic characteristics and to living and working conditions, highlighting the association with environmental pollutants; the second relating infectious and parasitic diseases to precarious socio-environmental conditions, such as absent or ineffective sanitation; and the third connecting situations of violence and accidents to health-disease processes.

Several studies on determinants of respiratory diseases in general, conducted by Antunes et al. (2014), in different regions of Salvador, BA, and on the incidence of tuberculosis, conducted by Acosta and Bassanesi (2014), in different regions of the city of Porto Alegre, RS, also identified an association between schooling, income, sanitation services, health services, and characteristics and location of the houses and a higher number of cases. The relationship between atmospheric contaminants and health problems is also the focus of research studies carried out by Silva et al. (2017), Abe and Miraglia (2018) and Corá et al. (2020), drawing attention to determinants related to industrialization, urban mobility, and the importance of public policies for transportation and air pollution control.

Sociodemographic variables and environmental and structural conditions are considered in the research study by Honorato et al. (2014), conducted in the state of Espírito Santo, as important determinants to understand and fight dengue. The authors recognized deficient or absent sanitation and precarious housing, especially in contexts of social inequality in large urban agglomerations, as factors that contribute to maintaining the number of disease cases and/or increasing its incidence. Similarly, health risks and problems associated with precarious sanitation services are surveyed and discussed in the studies by Ogata et al. (2016) on the quality of drinking water; by Chayb and Kozusny-Andreani (2015) on the presence of pathogens in different types of waste, with emphasis on the risks of contamination of household waste; and by Lobato and Jardim (2014) on diseases related to inadequate environmental sanitation.

The approach of socio-environmental determinants is also considered in the Health Impact Assessment (HIA), recommended by the WHO and widely disseminated and used in other countries, associated with environmental licensing processes of large enterprises, which require planned and complex actions. This methodology, still not widely used in Brazil, analyzes, in association with the social players involved, both positive and negative aspects of health resulting from interventions in a territory, whether originating from projects, programs, plans, 
or public policies. It does not overlap with other assessments, so it is possible to consider the health variable that is generally not taken into account in these studies by the decision-maker (Silveira and Fenner, 2017).

Cassol (2012) and Camponogara et al. (2013) address the importance of this expanded and systemic perspective to health, considering its multi-causality and the various socio-environmental contexts that impact it, as well as the role and appreciation of the health professionals working in Primary Care, such as the CHAs. In the opinion of these authors, the research studies carried out evidenced knowledge of the territory by these professionals, as they work and live there, which is fundamental to enhance the actions focused on the complexity of the socio-environmental determinants of health.

Experiences developed by the Manguinhos Territorial Laboratory (Laboratório Territorial de Manguinhos, LTM) also seek to enhance the actions of FHS teams and the integration of different knowledge by proposing "extended action research communities", consisting of researchers from Fiocruz and other institutions, residents of Rio de Janeiro informal settlements (Manguinhos, Alemão, and Rocinha), and health professionals working in these locations, to brainstorm and seek more efficient collaborative solutions to issues associated with socio-environmental determinants, in contexts of high vulnerability (Porto et al., 2015).

It is also emphasized that important advances are acknowledged by Borde et al. (2014) in mapping research studies about the social determinants of health in Brazil since the creation of the National Commission on Social Determinants of Health, in terms of number and quality of research studies. In turn, as highlighted by the authors, there are still enormous regional and intra-urban differences in the country in terms of urban sprawl and peripheralization, not often considered in research studies using data from information systems with indicators generally based on a mean value that does not reflect actual social inequalities. In addition to that, despite the search for bringing science, politics, and society closer together through innovative research processes on this theme, these are still very scarcely reflected in public policies aimed at reducing situations of vulnerability and, consequently, inequalities. This is due to the challenges associated, for example, with the communication, evaluation, and research processes themselves, which are still very restricted to the academic population, either in their production or dissemination, and interact very little with other relevant social players, such as technical professionals from governmental sectors in the various areas involved.

\section{Territory under analysis and urban planning}

Paraisópolis, the territory under analysis in this article, is the second-largest informal settlement in São Paulo, with nearly 80,000 inhabitants, most of them living in areas of high socio-environmental vulnerability, overlapping risks, and health inequalities.
The area is divided into seven different sectors, five of them located in the main cluster, and two in satellite clusters. These sectors are characterized by different degrees of access to infrastructure and public services, according to a survey commissioned by the $\mathrm{Mu}$ nicipal Housing Secretariat (Secretaria Municipal de Habitação, SE$\mathrm{HAB}$ ) in 2004 and analyzed by several authors (Rezende and Alvim, 2016; Maziviero and Silva, 2018).

The main cluster belongs to the Campo Limpo District Council and, according to the 2004 survey, it had 17,184 households in $1 \mathrm{Km}^{2}$ approximately at that time. The Southeast quadrant, composed of the Grotão and Grotinho sectors, was the most vulnerable and concentrated nearly $30 \%$ of the households with the worst indicators of access to sewage, electricity, and waste collection compared to the other sectors.

The West Antonico sector concentrates the largest number of households and is cut by the stream that gives the sector its name. To the East of the stream there are the two BHUs located within the main cluster, 500 meters apart from each other in the North-South direction. The Figure 1 shows the location of the BHUs and the main territorial frameworks of the main cluster.

The survey commissioned by the SEHAB in 2004 was part of a strategy for the management of the areas occupied by the population in situations of social vulnerability. These areas were included in urban consolidation and public service strategies after the institution of the Special Social Interest Zones by the São Paulo Strategic Master Plan in 2002. Therefore, since the 2004 survey, several improvements have been made in the complex; however, there is

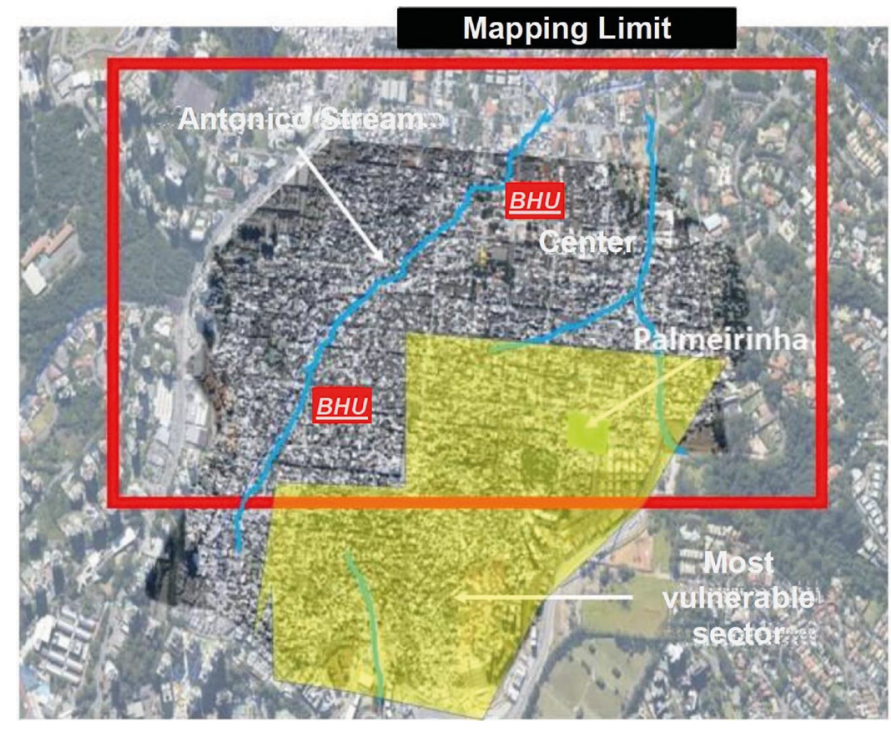

Figure 1 - Map of the main cluster of Paraisópolis. It includes the indications corresponding to the two BHUs located within the cluster, the Antonico stream, the central sector, the vulnerable sectors, and the Palmeirinha field. 
still a major lack of infrastructure works and services, as shown in this article.

Maziviero and Silva (2018) provide a history of interventions initiated and carried out in the Paraisópolis complex, during the municipal administrations of Marta Suplicy (2001-2004), José Serra (2005-2008), Gilberto Kassab (2009-2012), and Fernando Haddad (2013-2016). According to data presented by the authors, in the first three administrations analyzed, nearly $90 \%$ of the water and sewage networks were implemented, in addition to paving works. Despite that, the drainage and stream canalization works were carried out in a much smaller proportion than necessary. The authors' survey maps 19 works finished between José Serra and Fernando Haddad administrations, as well as two unfinished works. In their vast majority, these works met the two most vulnerable sectors of the complex. In these sectors, the urbanization of Palmeirinha (2005-2008) was carried out, in addition to two schools and a Unified Educational Center (Centro Educacional Unificado, CEU) (2005-2008), eight housing undertakings (20092012), a BHU (2009-2012), a State Technical School (Escola Técnica Estadual, ETEC) (2009-2012), and two social devices (2013-2016). Regarding the canalization and drainage works of the streams that cut through the area, only the Swamp was delivered during Haddad's administration.

Rezende and Alvim (2016) provide an overview of the 19 projects developed and not implemented for the complex since 2001. Many of these include linear parks, urbanization works, and innovative housing solutions which would undoubtedly contribute to solving many of the complex's environmental problems if they had been implemented. This is the case, for example, of the works planned for the Antonico stream in 2012, which were not executed, and which could have a major socio-environmental impact on the Paraisópolis complex, since it is located in an area with the highest number of houses. Execution of this work is in the guidelines indicated in the Regional Plan Folder of the Campo Limpo District Council (Prefeitura de São Paulo, 2016a, 2016b).

Participatory master plans were defined by the City Statute (Federal Law 10, 257 of 2001) and, in the city of São Paulo, it was the Master Plan approved in 2002 that instituted a local planning system based on the creation of District Councils (formerly regional administrations) and mandatory regional plans. Although operative, these local instances of city planning fail to achieve the desired representativeness. The regional plans still represent the weakest link of the general city planning system. Nevertheless, regional plans strengthen local governance, as they more directly deal with the city's specific problems. In addition, it is acknowledged that the mobilizing potential of mapping socio-environmental determinants is still little explored by interdisciplinary urban studies, which could strengthen the institutional mechanisms of urban planning and social control at the local level.

\section{Understanding participatory} planning and its applications

In the current COVID-19 pandemic context, which more strongly affected the world throughout most of 2020, huge social inequalities, especially in developing countries and their peripheral metropolitan areas, have highlighted the importance and urgency of tools that expand social inclusion in the decision-making process for more sustainable and efficient urban planning. PGIS are tools that combine technical expertise in GIS with community knowledge produced along with citizens, and can be used both by experts and community members in their planning and decision-making processes (McCall, 2004; Fagerholm et al., 2021).

Based on the need to bring science and society closer together, creating a bridge between planners and citizens, PGIS emerged in the 1990s, integrating people's perceptions and knowledge with spatial techniques (Ferreira et al., 2017). It is based on a method called SoftGIS, which is a multidisciplinary approach incremented in Finland by researchers in the PGIS field, whose main purpose is to support planning and decision-making, including a better understanding of local knowledge and how citizens perceive their environment, from their involvement in this participatory mapping process and its integration with urban planning activities and phases. The term SoftGIS refers to the subjective and also qualitative nature of the data collected together with the citizens, as opposed to the HardGIS designation, which consists of, for example, the collection and use of data from official agencies or traditional maps, commonly used in GIS (Kahila-Tani et al., 2019). The main objective is to integrate this co-produced knowledge and improve local living conditions (Kahila-Tani et al., 2016).

PGIS can even provide social innovation and change, for example, by favoring social sustainability and justice practices along with vulnerable communities. By means of its participatory process, PGIS promotes better collective decisions, through social learning and the consequent empowerment of those who participate in its development, by the collaborative construction of knowledge in the various stages of this process (Kahila-Tani et al., 2019). Thus, with the incorporation of narratives, perceptions, and values of the social players participating in georeferencing, a technological component with high social innovation potential is obtained (Cidell, 2008).

The PGIS method can be applied and developed in several ways, according to the target audience to be worked on, such as traditional mapping with the use of GPS and topographic maps, talking maps - an instrument applied in the research reported herein - scale maps, three-dimensional maps and models; interpretation of satellite images and aerial photos, and tools that use the Internet, such as the OpenStreetMap (OSM) free platform. As already mentioned, community data can be treated both quantitatively and qualitatively given the wide variety of instruments mentioned that can be used. Since every point marked on a map has a history, with the support 
of geoprocessing techniques and spatial analysis, more accurate diagnoses are performed, as well as spatial analysis, such as calculating distances and formulating strategies for local improvements (Rantanen and Kahila, 2009). In addition, SoftGIS data can be confronted with HardGIS data for a comparison between citizens' perception and the current structure of the place under study, enriching the analyses produced (Kahila-Tani et al., 2016). Thus, participatory mapping and the construction of PGIS with the data collected are a fundamental environmental and urban planning tool, aimed at different approaches, such as tourism and ecotourism, risk and disaster management, environmental/public health, mobility, evaluation of ecosystem services, green and blue urban areas, sanitation, studies on marginalized social groups, among others.

In addition to that, due to its participatory, reflective, and dialogic nature, and because it contributes to the process of democratizing science, PGIS shares the principles of both action research (Toledo and Giatti, 2015) and Freire's Research Itinerary, the Circles of Culture (Freire, 2019), methodological approaches guiding the research herein analyzed. In health, the main contributions are territory appropriation by CHAs and other health professionals, and the establishment of bonds between the professionals and the population, through territory mapping, in addition to maximizing the potential of the analyses produced and improvements in the performance and communication between the stakeholders (Goldstein et al., 2013). Currently, some participatory mapping initiatives support communities vulnerable to the COVID-19 pandemic, such as the participatory mapping promoted by UNHabitat, which maps out good practices for informal settlements in several countries to cope with the pandemic (UNHabitat, 2020).

\section{Map production in the territory of Paraisópolis, in the context of action research}

As part of an action research process (Toledo and Giatti, 2015), between February and May 2019, four meetings were held in the form of Culture Circles (Freire, 2019) at Paraisópolis II BHU, with the participation of 29 CHAs from the six local health teams. These meetings were mediated by the coordinating nurse of one of these teams, who is also one of the authors of this article, and who has been working in this territory since 2012. Therefore, the coordinating nurse has a pre-established relationship of trust and bond with the CHAs participating in this action research, as expected from methodological approaches of this nature, thus enabling the path of Freire's Research Itinerary in four meetings, following the stages of thematic investigation, problematization or coding and decoding, and critical unveiling (Freire, 2019; Santos and Toledo, 2020).

The objectives of the first meeting, held in February 2019, were to present the research, answer questions, and acknowledge the expectations of the participating CHAs. In the following meeting, in
March 2019, the generating themes were surveyed, based on the identification and mapping of socio-environmental determinants of health, according to the perception of the CHAs participating in the research (thematic investigation stage). Health education processes around the issues surveyed and potential relationships between the determinants and health were also concurrently developed in this meeting and the third meeting, held in April 2019, integrating technical knowledge and local traditional knowledge (coding and decoding stage). In the last meeting, in May 2019, it was sought to recognize ways to qualify the CHAs' health education and promotion practices, based on this mapping and collaborative learning process (critical unveiling stage) (Santos and Toledo, 2020).

Considering that the focus of this article is the analysis of a participatory mapping of socio-environmental determinants, further details of the action research process and Paulo Freire's Research Itinerary (the Culture Circles) stages, as well as of the instruments and socio-educational strategies used in this research, can be found in Santos and Toledo (2020).

The participatory mapping of the socio-environmental determinants of health, the focus of this article, was then initiated in the second meeting, which took place on March $12^{\text {th }}, 2019$, lasting four hours, for which the Talking Map construction technique was used. It is a diagnostic and/or planning instrument, which must be collectively prepared with the purpose of graphically representing (using drawing and/or collages) a certain situation or reality. When completed, it must be presented (the maps are given a "voice") to promote a debate. By favoring reflection, dialog, and search of consensus among the participants, a space for social and educational processes is also created (Toledo and Giatti, 2015; Toledo et al., 2020).

On previously printed maps of the six FHS coverage areas of Paraisópolis II BHU, the CHAs, divided into six groups, were then encouraged to represent, through drawings, local socio-environmental determinants that, according to their perception, could positively or negatively influence the health of Paraisópolis residents and, at the end of the drawings, a representative of each group presented their "map". Among the negative aspects represented and/or mentioned, it is possible to name the following: inadequate disposal of waste on the streets and streams; open sewage; pet abandonment; vector animals (rats, cockroaches, etc.); humid, poorly ventilated wooden houses ("shacks") that are very close together,; drug use and trafficking; accumulators (of objects, animals, garbage); sexual abuse; and people's lack of care and respect towards the physical space and the community (people are not aware of collective well-being, cars on the sidewalks, and loud music). Among the positive aspects, the following stand out: the varied commercial establishments (bakery, markets, pizzerias, butcher shop, stores, and bars); the BHU, the Specialist Outpatient Clinics (Ambulatório Médico de Especial- 


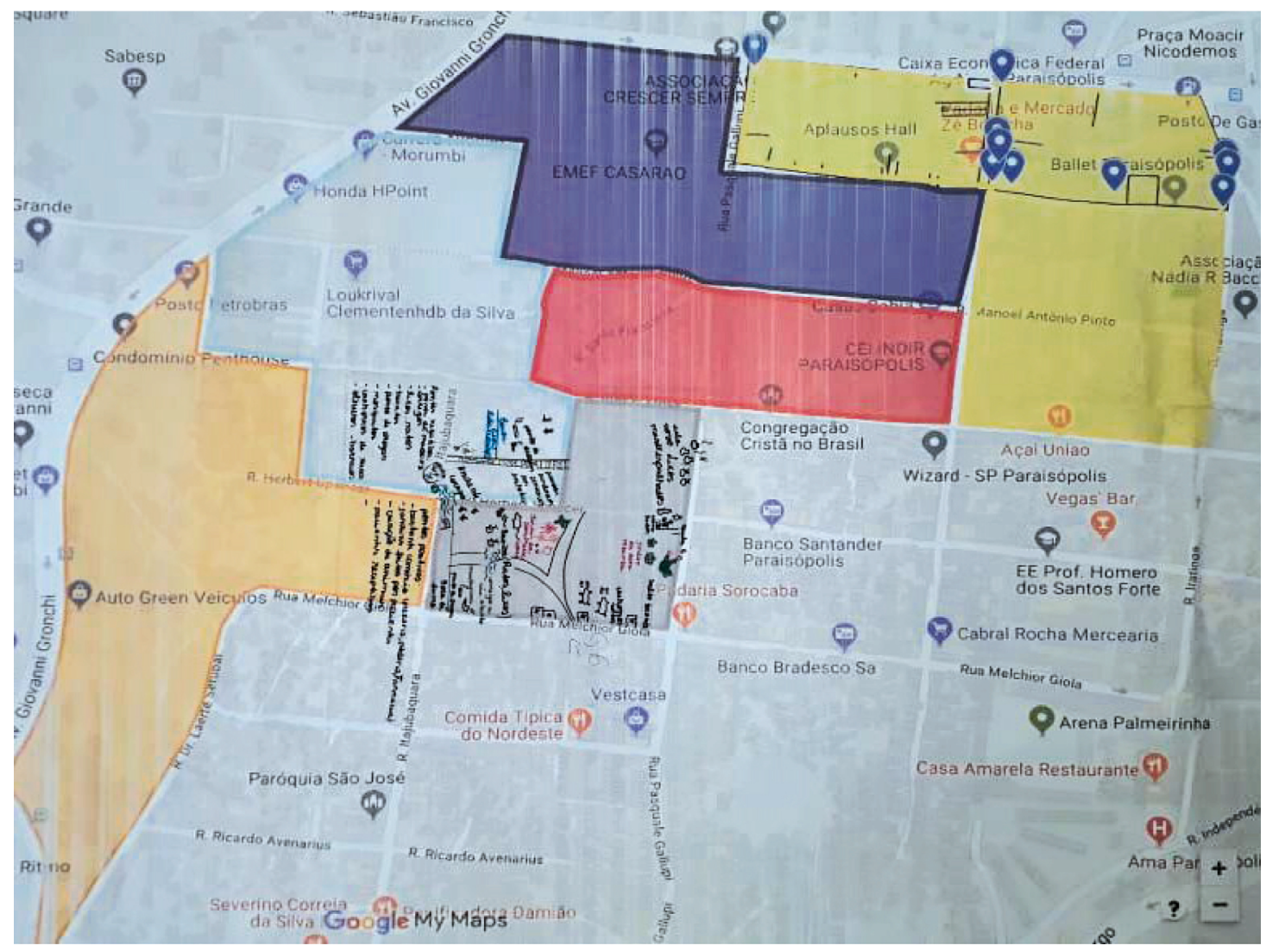

Figure 2 - One of the talking-maps produced by the CHAs about socio-environmental determinants of health in the FHS territory of the Paraisópolis II BHU, 2019.

idades, AME), dentists, CHAs, Outpatient Medical Care (Assistência Médica Ambulatorial, AMA), and the Psychosocial Care Center (Centro de Atenção Psicossocial, CAPS); the social projects and non-governmental organizations (NGOs) such as Bom Prato, Casa da Mulher, etc.; the spaces for leisure and sports, such as courts, ballet school; trees on the streets and yards in the houses; the schools and "mães crecheiras" ("childcare mothers"), who are willing to take care of children at their homes; good acceptance by patients; and the churches (Santos and Toledo, 2020).

The following are images of one of the maps worked on by one of the CHA groups, in which the micro-areas attached to Paraisópolis II can be seen, distinguished by colors (Figure 2); and of approximate clippings of some aspects represented by the CHAs in each micro-area (Figure 3).

The socio-environmental determinants of health, represented and mentioned in the CHAs' presentations, were categorized, by similarity and as suggested by the CHAs, into generating themes (thematic investigation stage of Freire's Research Itinerary - Culture Circles) during the process of building these talkingmaps. They were as follows: poor sanitation, animals, housing and other facilities, social issues/violence, and behavioral factors (categories of generating themes - negative socio-environmental determinants); commerce; health services, NGOs/social projects, sports and leisure, green areas, education, behavioral factors, animals, and churches (categories of generating themes - positive socio-environmental determinants). These generating themes were then addressed in more detail in the following meetings, trying to codify them, that is, to contextualize them in the reality experienced by the CHAs and decode them by the notion of socio-environmental determinants of health, trying to understand how they operated to generate inequalities and situations of vulnerability in Paraisópolis community, through a shared process of education in health (Santos and Toledo, 2020).

The socio-environmental determinants recognized by the CHAs in this research are in agreement with those that have been reported in the literature, both from a conceptual point of view (CSDH, 2008; Sobral and Freitas, 2010; Akerman et al., 2011) and in association studies (Cassol, 2012; Acosta and Bassanesi, 2014; Antunes et al., 2014; Honorato et al., 2014; Lobato and Jardim, 2014; Chayb and Kozusny-Andreani, 2015; Ogata et al., 2016; Silva et al., 2017; Abe and Miraglia, 2018; Corá et al., 2020). 


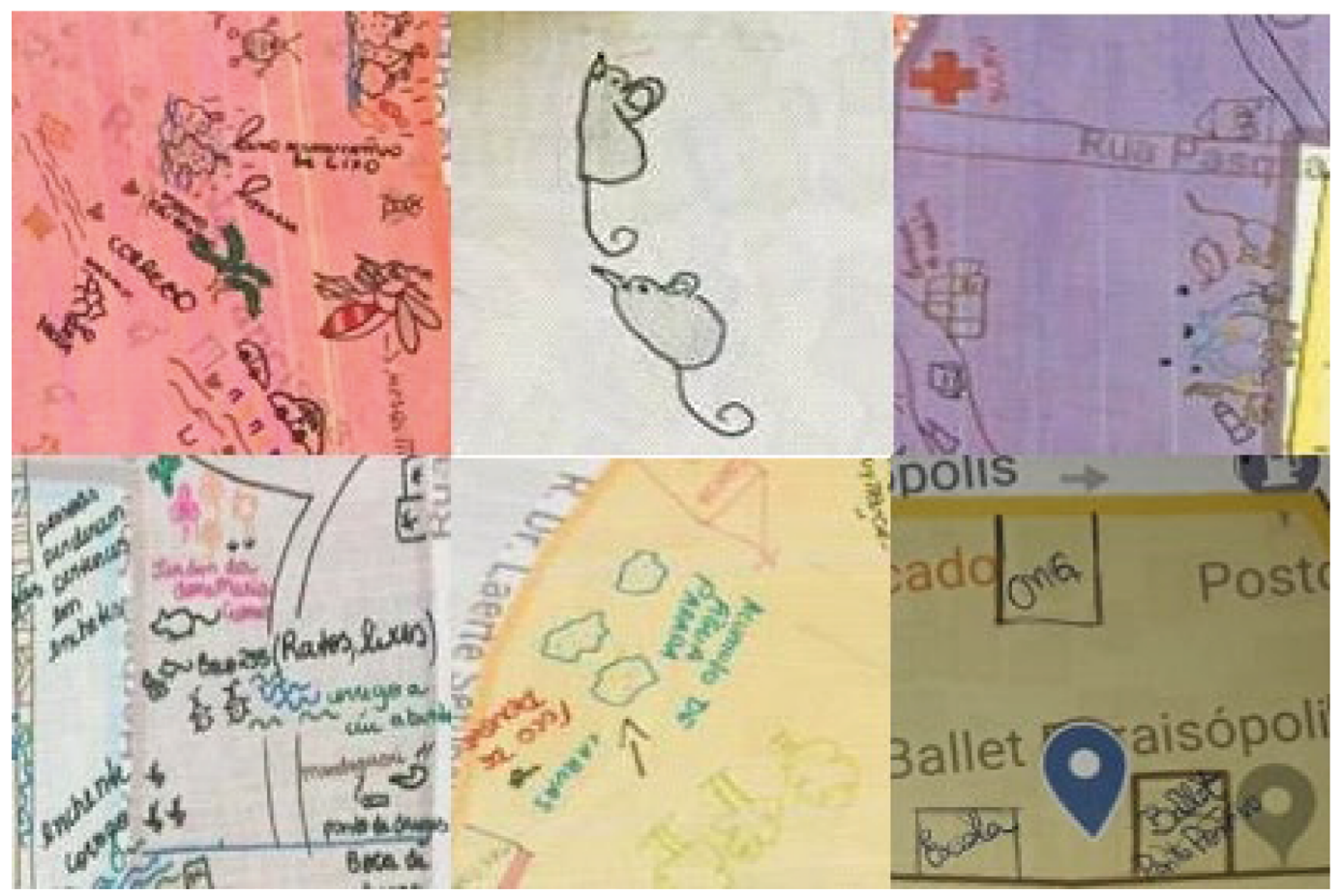

Figure 3 - Clippings from the Talking-maps produced by the CHAs about socio-environmental determinants of health in the FHS territory of Paraisópolis II BHU, 2019.

Source: Santos and Toledo (2020).

Also, according to Porto et al. (2015), the various socio-environmental problems found in vulnerable communities, such as the lack of basic sanitation, respiratory problems, and drug use and abuse, among others, make up a serious and complex scenario, with the FHS and the CHA performance being a very important reference of care for the population. This is because this complexity is evident in tangible social determinants, clearly recognized by economic, environmental, social, and epidemiological data. But it is also present in intangible determinants, in the way local residents and professionals from these territories perceive and assess their living conditions.

To expand this perception and analyze its potential for territory management and planning, during the process, the talking maps were georeferenced. This means the negative and positive socio-environmental determinants recognized and mapped by the CHAs were referenced in known geographical coordinates, with the use of the QuantumGIS free software, configuring a database or PGIS.

Each point mapped out by the CHAs was manually digitalized with the software, generating a final map of points overlaid on the OpenStreetMap street layer. This street layer is intended for local orientation, and was also used as the basis to generate the talking maps. For analysis purposes, other information plans can be added, such as other health data considered relevant. However, the research reported herein focused on the participatory mapping of the socio-environmental determinants of health.

Therefore, the following maps (Figures 4 and 5) represent the perception and knowledge of the CHAs working in Paraisópolis II BHU, produced in a team effort during this action research. The first version of these maps was presented to the CHAs at one of the Culture Circles meetings (on May $14^{\text {th }}, 2019$ ) so that they could give their opinions on the colors, symbols, and shapes that were used. For ethical reasons, it was decided not to geo-reference socio-environmental determinants associated with violence issues (such as drug consumption and trafficking points).

Also, in this meeting, and from the analysis of the georeferenced maps through a free conversation circle, the CHAs were invited to reflect on whether these maps could assist in the work of the health teams. It was asked, for example, if the community had access to this material, whether this could contribute to qualifying the process of education and health promotion and how, as well as other actions of the health teams. This seems to be the case, as ob- 


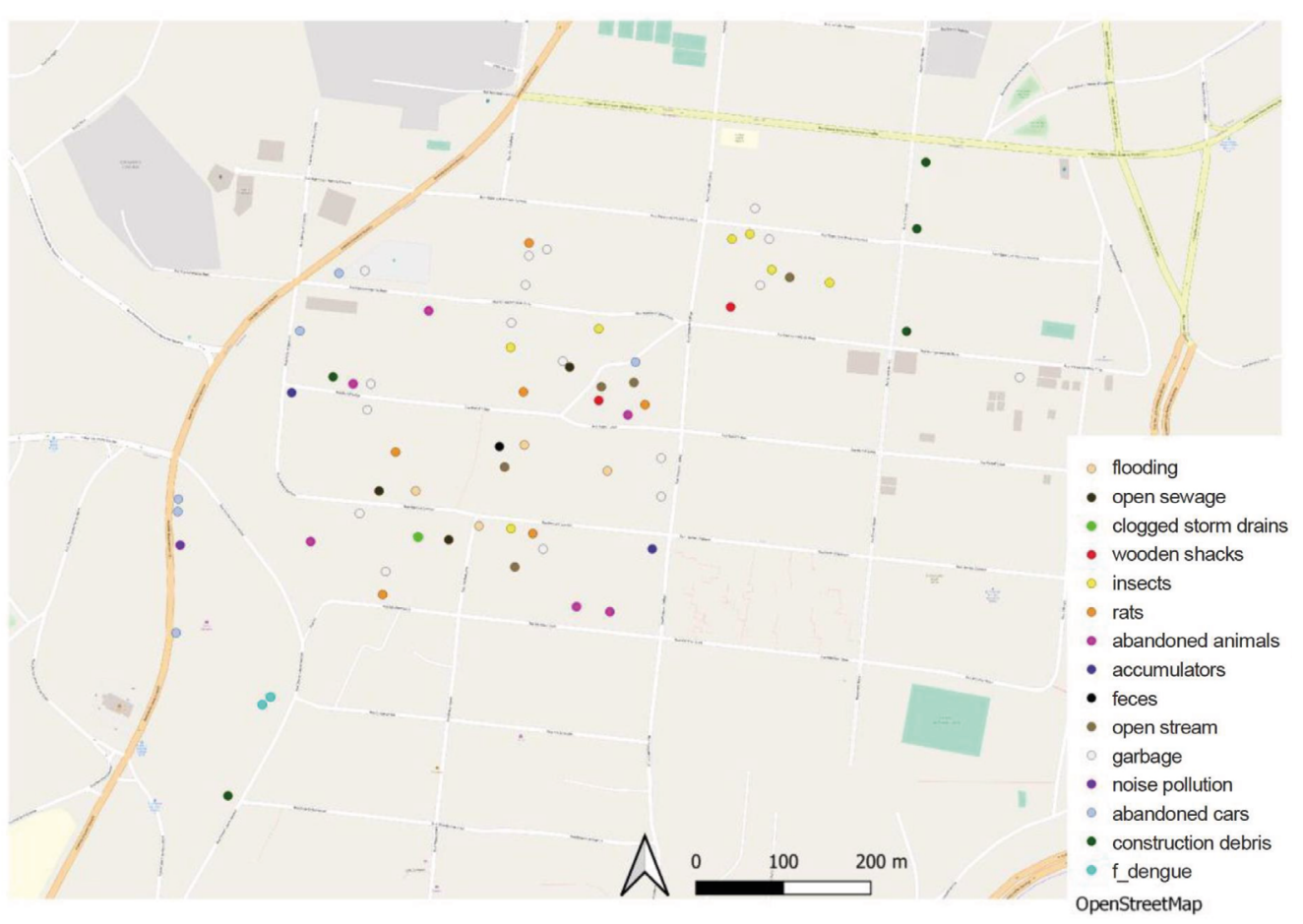

Figure 4 - Map of socio-environmental determinants with a negative influence on health in the territory covered by Paraisópolis BHU, SP, according to the perception of CHAs, 2019.

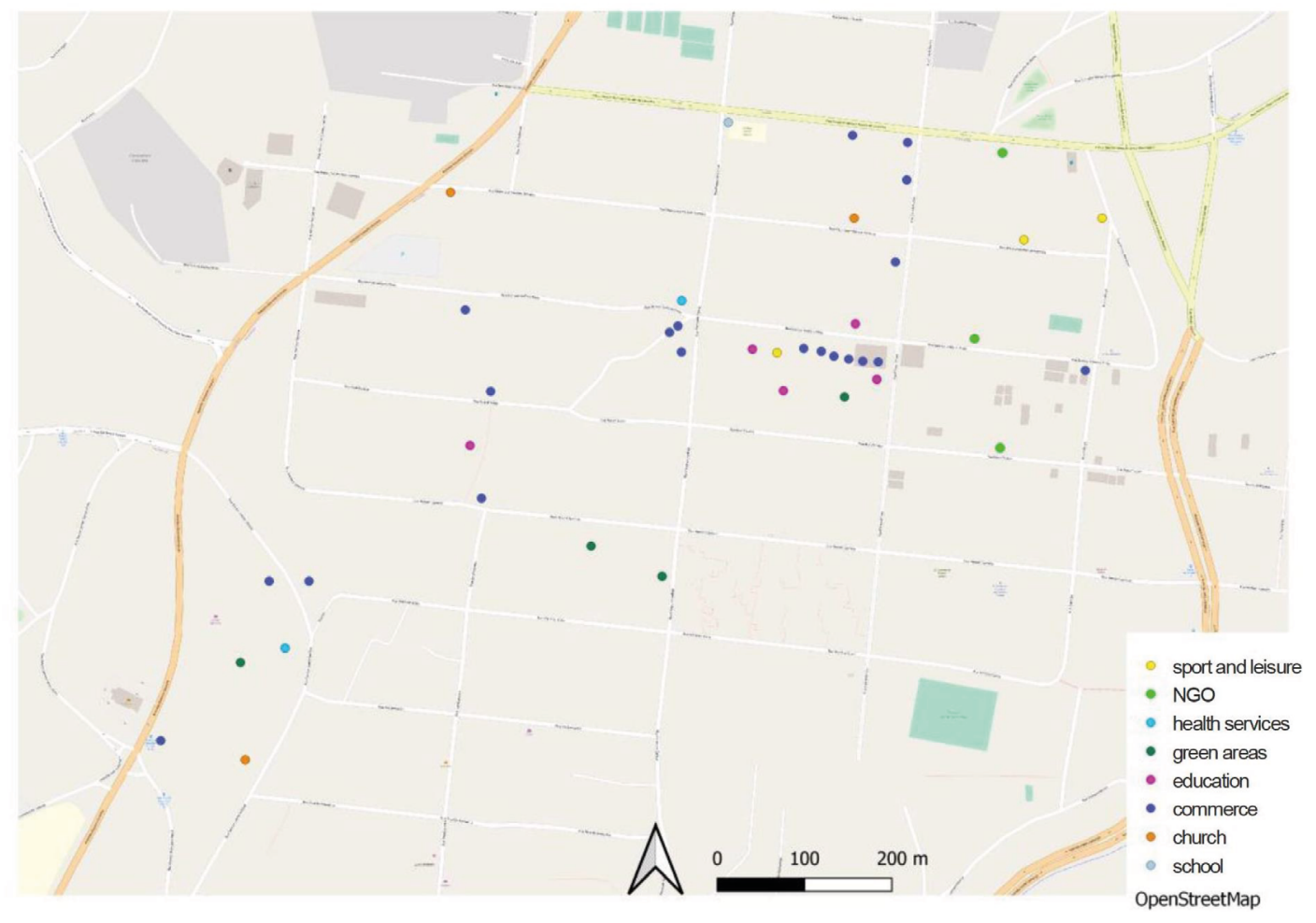

Figure 5 - Map of socio-environmental determinants with a positive influence on health in the territory covered by Paraisópolis BHU, SP, according to the perception of CHAs, 2019. 
served from these statements: "it's a good idea because, normally, the patients can only see their own problems, but having a broader view can help them to reflect"; "it's important to show problems on a map because sometimes the patients think they are the only ones facing a particular problem. But seeing that other people go through the same situation, maybe the patients will understand that it's not something easy to solve as they believe". Some CHAs also suggested using the maps in the work teams to facilitate approaching the theme of socio-environmental determinants (Santos and Toledo, 2020).

The trigger for greater territory appropriation by Primary Care health professionals, especially CHAs, as a result of more opportunities for dialog and participation, and their contributions to understanding and coping with local demands, is also evidenced in the literature (Camponogara et al., 2013; Goldstein et al., 2013; Bezerra and Feitosa, 2018; Salinas Rebolledo et al., 2018; Faria and Paiva, 2020; Silva et al., 2020).

Finally, the participatory production of these maps allowed the CHAs involved not only to recognize the combination of some socio-environmental determinants present in the location, but also to better understand that such a combination can increase situations of vulnerability. This is because living in areas at risk that have not been effectively urbanized, with absent or poor sanitation, precarious houses and consequently unhealthy conditions, poverty, violence, social exclusion, among others, are factors that overlap in the territory and which, according to Smith and Ezatti (2005), can occur in the homes, in the community, or they can be associated with public policies and global phenomena.

\section{Conclusions}

The analyses carried out from the results of this research showed that, through the PGIS and participatory mapping, citizens can more effectively recognize and communicate their needs and, thus, intervention strategies in the territory and local maintenance actions can more representatively address the residents' priorities for the improvement of their towns. Participatory mapping shows itself as a powerful instrument to stimulate participatory urban management and planning, integrating different social players, especially in towns with traditionally marginalized social groups.

In the case of CHAs, who play a central role in the research under analysis, they are essential to drive, mobilize, and support the complex aspects involved, both in Primary Health Care and urban management and planning because they live and work in the same place. They are health-promoting professionals who are sensitive to the needs of the territory, interacting in real-time with the difficulties, and even network with other health professionals, that is, providing a collaborative learning process to the entire team. The research evidenced that living in a community favors a better understanding of the most urgent needs and situations that can harm the population more seriously. When mapping socio-environmental determinants of health, among the most relevant aspects, were absent or poor basic sanitation, unhealthiness in housing, commercial sites, and green areas, among others, which are also determinants directly related to the urban management and planning needs.

The results of this research and its dissemination also meet the objectives of the World and National Commissions on Social Determinants of Health by contributing to generating and expanding information and knowledge networks, producing scientific evidence on the subject matter, increasing mobilization around the theme, and stimulating the qualification of environmental, social, health, and urban planning public policies that promote equality.

Although participatory mapping develops territorial approaches that allow for relevant intersectoral dialogs at the local level, the several knowledge and cultural competencies of these players, such as the CHAs, have to be more fully recognized. Also, clearer strategies must be formulated for including these professionals in the local city planning and management system to achieve sustainable development and reduced local inequality in vulnerable areas.

It is therefore considered that this mapping and its analysis, originated and developed as a demand perceived during this action research process, has the potential to positively impact aspects related to health, environmental, social, educational, cultural, and urban planning, in the territory covered by the FHS, of Paraisópolis II BHU in Paraisópolis community, city of São Paulo (state of São Paulo).

The innovative character and replicability potential of socio-environmental determinant mapping by the PGIS in other locations is also highlighted. Talking map techniques can be integrated, configuring a Geographic Information System. From its collaborative production and dissemination in different communication channels, such as the community and technical-scientific ones, this product is expected to contribute to qualifying health promotion, education, and environmental education actions, as well as expanding social mobilization and improving planning and governance processes, advancing towards sustainability.

In terms of future perspectives, it is also considered that the products generated in processes of this nature have enormous potential for solid developments in local governance, such as in neighborhood planning, which can later be integrated into District Council local planning for the area where they are produced, becoming a part of the city's general planning system, contributing to solid improvements in different towns in the future. 


\section{Contribution of authors:}

Toledo, R.F.: Conceptualization, Methodology, Validation, Formal analysis, Investigation, Data curation, Writing — original draft, Supervision, Writing — review \& editing; Koury, A.P.: Conceptualization, Validation, Formal analysis, Writing — original draft, Writing - review \& editing; Carvalho, C.M.: Conceptualization, Methodology, Software, Validation, Formal analysis, Investigation, Writing — original draft, Writing — review \& editing; Santos, F.N.P.: Conceptualization, Methodology, Validation, Formal analysis, Investigation, Data curation, Writing — original draft, Writing — review \& editing.

\section{References}

Abe, K.; Miraglia, S., 2018. Avaliação de impacto à saúde do programa de controle de poluição do ar por veículos automotores no município de São Paulo, Brasil. Revista Brasileira de Ciências Ambientais, (47), 61-73. https:// doi.org/10.5327/Z2176-947820180310.

Abranches, M., 2020. Planejamento urbano participativo: o mapeamento dos problemas da cidade pelos seus diversos atores. Cajuína, Cotia, 124 pp.

Acosta, L.M.W.; Bassanesi, S.L., 2014. O paradoxo de Porto Alegre: determinantes sociais e incidência de tuberculose. Revista Brasileira de Epidemiologia, v. 17, (Supl. 2), 88-101. https://doi.org/10.1590/1809-4503201400060008.

Akerman, M.; Maymone, C.C.; Gonçalves, C.B.; Chiaro, A.; Buss, P.M., 2011. As novas agendas de saúde a partir de seus determinantes sociais. In: Galvão, L.A.C.; Finkelman, J.; Henao, S. (Eds.), Determinantes ambientais e sociais da saúde. Opas; Editora Fiocruz, Rio de Janeiro, pp. 1-15.

Almeida, L.S.; Cota, A.L.S.; Rodrigues, D.F., 2020. Saneamento, Arboviroses e Determinantes Ambientais: impactos na saúde urbana. Ciência \& Saúde Coletiva, v. 25, (10), 3857-3868. https://doi.org/10.1590/1413812320202510.30712018

Antunes, F.P.; Costa, M.C.N.; Paim, J.S.; Cruz, A.; Silva, L.M.V.; Barreto, M., 2014. Determinantes sociais dos diferenciais intraurbanos das internações por doenças respiratórias em Salvador (BA), Brasil. Revista Brasileira de Epidemiologia, v. 17, (Supl. 2), 29-38. https://dx.doi.org/10.1590/1809-4503201400060003.

Arcoverde, M.A.M.; Berra, T.Z.; Alves, L.S.; Santos, D.T.; Belchior, A.S.; Ramos, A.C.V.; Arroyo, L.H.; Assis, I.S.; Alves, J.D.; Queiroz, A.A.R.; Yamamura, M.; Palha, P.F.; Chiaravalloti Neto, F.; Silva-Sobrinho, R.A.; Nihei, O.K.; Arcêncio, R.A., 2018. How do social-economic differences in urban areas affect tuberculosis mortality in a city in the tri-border region of Brazil, Paraguay and Argentina. BMC Public Health, v. 18, (1), 1-14. https://doi.org/10.1186/ s12889-018-5623-2.

Arouca, M.G.; Neves, I.B.C.; Brito, R.L., 2019. +Lugar: Um aplicativo gamificado destinado à saúde coletiva. Anais do Seminário Tecnologias Aplicadas a Educação e Saúde (Accessed Oct. 12, 2019) at: https://revistas. uneb.br/index.php/staes/article/view/8224.

Bezerra, Y.R.N.; Feitosa, M.Z.S., 2018. A afetividade do agente comunitário de saúde no território: um estudo com os mapas afetivos. Ciência \& Saúde Coletiva, v. 23, (3), 813-822. http://dx.doi.org/10.1590/141381232018233.00292016 .

Borde, E.; Akerman, M.; Pellegrini Filho, A., 2014. Mapeamento das capacidades de pesquisa em saúde e seus determinantes sociais no Brasil. Cadernos de Saúde Pública, v. 30, (10), 2081-2091. https://doi. org/10.1590/0102-311X00162513.

Brasil. 1990. Lei Federal Brasileira no 8.080, de 19 de setembro de 1990. Lei Orgânica da Saúde. (Accessed Sep. 21, 2019) at: http://www.planalto.gov.br/ ccivil_03/leis/18080.htm.
Brasil. 2001. Lei Federal Brasileira ${ }^{\circ}$ 10.257, de 10 de julho de 2001. Estatuto da Cidade. (Accessed Dec. 2, 2019) at: http://www.planalto.gov.br/ccivil_03/ leis/leis_2001/110257.htm

Brasil. 2018. Lei Federal Brasileira $n^{\circ} 13.595$, de 5/1/2018. Altera a Lei ${ }^{\circ}$ 11.350 , de 5/10/2006, para dispor sobre a reformulação das atribuições, a jornada e as condições de trabalho, o grau de formação profissional, os cursos de formação técnica e continuada e a indenização de transporte dos profissionais Agentes Comunitários de Saúde e Agentes de Combate às Endemias (Accessed Sep. 21, 2019) at: http://www.planalto.gov.br/ccivil_03/_ Ato2015-2018/2018/Lei/L13595.htm\#art1.

Camponogara, S.; Erthal, G.; Viero, M.C., 2013. A problemática ambiental na visão de agentes comunitários de Saúde. Ciência, Cuidado e Saúde, v. 12, (2), 233-240. https://doi.org/10.4025/cienccuidsaude.v12i2.18584.

Carmo, M.E.; Guizardi, F.L., 2018. O conceito de vulnerabilidade e seus sentidos para as políticas públicas de saúde e assistência social. Cadernos de Saúde Pública, v. 34, (3), e00101417. https://doi.org/10.1590/0102$311 \times 00101417$

Carvalho, C.M.; Giatti L.L., 2018. Participatory GIS for urban sustainability and resilience: a perspective of social learning and ecology of knowledge. In: Azeiteiro, U.; Akerman, M.; Leal Filho, W.; Setti, A.; Brandli, L. (Eds.). Lifelong learning and education in healthy and sustainable cities. World Sustainability Series. Springer, Cham, pp. 21-34. https://doi.org/10.1007/978-3-319-69474$0 \_2$.

Cassol, P.B., 2012. A gerontologia interface o meio ambiente como estratégia no cuidado e promoção da saúde. Revista Eletrônica em Gestão, Educação e Tecnologia Ambiental, v. 6, (6), 1043-1048. http://dx.doi. org/10.5902/223611704959.

Chayb, E.; Kozusny-Andreani, D., 2015. Estudo comparativo da contaminação por micro-organismos patogênicos em resíduos domiciliares e de saúde em Uberlândia (MG). Revista Brasileira de Ciências Ambientais, (37), 72-87. https://doi.org/10.5327/Z2176-9478201512414.

Cidell, J., 2008. Challenging the contours: critical cartography, local knowledge, and the public. Environment and Planning A: Economy and Space, v. 40, (5), 1202-1218. https://doi.org/10.1068/a38447.

Cochrane, L.; Corbett, J., 2020. Participatory mapping. In: Servaes, J. (Ed.). Handbook of communication for development and social change. Springer, Singapore, pp. 705-713. https://doi.org/10.1007/978-981-15-2014-3_6.

Commission on Social Determinants of Health - CSDH, 2008. Closing the gap in a generation: health equity through action on the social determinants of health. Final Report of the Commission on Social Determinants of Health. World Health Organization, Geneva (Accessed Sep. 21, 2019) at: http://apps. who.int/iris/bitstream/10665/43943/1/9789241563703_eng.pdf.

Corá, B.; Leirião, L.; Miraglia, S., 2020. Impacto da poluição do ar na saúde pública em municípios de alta industrialização do estado de São Paulo. Revista Brasileira de Ciências Ambientais, v. 55, (4), 498-509. https://doi.org/10.5327/ Z2176-947820200671. 
Fagerholm, N.; Raymond, C.M.; Olafsson, A.S.; Brown, G.; Rinne, T.; Hasanzadeh, K.; Broberg, A.; Kyttä, M., 2021. A methodological framework for analysis of participatory mapping data in research, planning, and management. International Journal of Geographical Information Science, v. 35, (9), 18481875. https://doi.org/10.1080/13658816.2020.1869747.

Faria, C.C.M.V.; Paiva, C.H.A., 2020. O trabalho do agente comunitário de saúde e as diferenças sociais no território. Trabalho, Educação e Saúde, v. 18, (supl. 1), e0025183. https://doi.org/10.1590/1981-7746-sol00251

Ferreira, D.; Albino, L.; Freitas, M.J.C.C., 2017. Mapeamento participativo para a gestão de risco de desastres: região dos Baús, Ilhota-SC. Revista Brasileira de Cartografia, v. 69, (4), 713-730.

Fornace, K.M.; Surendra, H.; Abidin, T.R.; Reyes, R.; Macalinao, M.L.M.; Stresman, G.; Luchavez, J.; Ahmad, R.A.; Supargiyono, S.; Espino, F.; Drakeley, C.J.; Cook, J., 2018. Use of mobile technology-based participatory mapping approaches to geolocate health facility attendees for disease surveillance in low resource settings. International Journal of Health Geographics, v. 17. https:// doi.org/10.1186/s12942-018-0141-0.

Freire, P., 2019. Pedagogia do oprimido. Paz e Terra, Rio de Janeiro, 256 pp.

Freitas, Â.; Rodrigues, T.C.; Santana, P., 2020. Assessing urban health inequities through a multidimensional and participatory framework: evidence from the EURO-HEALTHY Project. Journal of Urban Health, v. 97, 857-875. https://doi.org/10.1007/s11524-020-00471-5.

Goldstein, R.A.; Barcellos, C.; Magalhães, M. de A.F.M.; Gracie, R.; Viacava, F., 2013. A experiência de mapeamento participativo para a construção de uma alternativa cartográfica para a ESF. Ciência \& Saúde Coletiva, v. 18, (1), 45-56. https://doi.org/10.1590/S1413-81232013000100006.

Honorato, T.; Lapa, P.P.A.; Sales, C.M.M.; Santos, B.R.; Tristão-Sá, R.; Bertolde, A.I.; Maciel, E.L.N., 2014. Análise espacial do risco de dengue no Espírito Santo, Brasil, 2010: uso de modelagem completamente Bayesiana. Revista Brasileira de Epidemiologia, v. 17, (supl. 2), 150-159. https://doi. org/10.1590/1809-4503201400060013.

Kahila-Tani, M.; Broberg, A.; Kyttä, M.; Tyger, T., 2016. Let the citizens map public participation GIS as a planning support system in the Helsinki master plan process. Planning Practice \& Research, v. 31, (2), 195-214. https://doi.org/ 10.1080/02697459.2015.1104203.

Kahila-Tani, M.; Kytta, M.; Geertman, S., 2019. Does mapping improve public participation? Exploring the pros and cons of using public participation GIS in urban planning practices, Landscape and Urban Planning, v. 186, 45-55. https://doi.org/10.1016/j.landurbplan.2019.02.019.

Lobato, G.; Jardim, M., 2014. Caracterização de indicadores de desenvolvimento sustentável na relação saúde e ambiente por meio das doenças relacionadas ao saneamento ambiental inadequado (DRSAI). Revista Brasileira de Ciências Ambientais, (33), 23-31 (Accessed Dec 13, 2019) at: http://www.rbciamb.com.br/index.php/Publicacoes_RBCIAMB/article/ view/230

Magalhães, T.C. 2021. Construção participativa do mapeamento do território da ESF Novo Tempo em Santa Helena de Minas: projeto de intervenção. Trabalho de Conclusão de Curso. Escola de Saúde Pública do Estado de Minas Gerais (Accessed Dec 13, 2019) at: http://repositorio.esp.mg.gov.br:8080/ xmlui/handle/123456789/375

Maman, S.; Lane, T.; Ntogwisangu, J.; Modiba, P.; Vanrooyen, H.; Timbe, A.; Visrutaratna, S.; Fritz, K., 2009. Using participatory mapping to inform a community-randomized trial of HIV counseling and testing. Field Methods, v. 21, (4), 368-387. http://doi.org/10.1177/1525822X09341718.
Mapping For Rights, 2020. Portal de dados abertos. Mapping For Rights, The Rainforest Foundation, UK (Accessed January 19, 2020) at: https://www. mappingforrights.org/participatory-mapping.

Maziviero, M.C.; Silva, A.S., 2018. O caso do COMPLEXO Paraisópolis em gestões: diferenças conceituais em programas de intervenção em favelas em São Paulo. Urbe Revista Brasileira de Gestão Urbana, v. 10, (3), 500-520. https://doi.org/10.1590/2175-3369.010.003.ao03.

McCall, M.K., 2004. Can participatory-GIS strengthen local-level spatial planning? Suggestions for better practice. GISDECO, Skudai, Johor, Malaysia.

Moraes, I.C.; Marengo, S.N.; Schacht, G.L.; Passos, D.S., 2021. Mapeamento participativo aplicado à Estratégia de Saúde da Família: a experiência em Santo Amaro, BA. Revista Brasileira de Cartografia, v. 73, (2), 646-665. https://doi. org/10.14393/rbcv73n2-56943.

Ogata, I.; Oliveira, R.; Meira, C.; Nascimento, R.; Henriques, J., 2016. Avaliação de risco à saúde associada à qualidade da água para consumo humano em Campina Grande, paraíba. Revista Brasileira de Ciências Ambientais, (40), 1-15. https://doi.org/10.5327/Z2176-947820160026.

Philippi Junior, A.; Andreoli, C.V.; Bruna, G.C.; Fernandes, V., 2014. Histórico e evolução do sistema de gestão ambiental no Brasil. In: Philippi Junior, A.; Roméro, M.A.; Bruna, G.C. (Eds.). Curso de gestão ambiental. $2^{\mathrm{a}}$ ed. Manole, Barueri, pp. 19-50. (Coleção Ambiental, v. 13).

Porto, M.F.S.; Cunha, M.B.; Pivetta, F.; Zancan, L.; Freitas, J.D., 2015. Saúde e ambiente na favela: reflexões para uma promoção emancipatória da saúde. Serviço Social \& Sociedade, (123), 523-543. https://doi. org/10.1590/0101-6628.035.

Prefeitura de São Paulo, 2016a. Cadernos de propostas dos planos regionais das subprefeituras: perímetro de ação - Campo Limpo). Prefeitura de São Paulo, São Paulo (Accessed Dec 13, 2019) at: https://gestaourbana.prefeitura. sp.gov.br/wp-content/uploads/2018/02/PA-CL.pdf.

Prefeitura de São Paulo, 2016b. Cadernos de propostas dos planos regionais das subprefeituras: quadro analítico - Campo Limpo. Prefeitura de São Paulo, São Paulo (Accessed Dec 2, 2019) at: https://gestaourbana.prefeitura.sp.gov.br/ wp-content/uploads/2018/02/QA-CL.pdf.

Programa das Nações Unidas para os Assentamentos - UNHabitat, 2020. Mapa de respostas Covid para favelas e assentamentos informais. Organização das Nações Unidas (Accessed January 19, 2020) at: https://unhab-cov19. ushahidi.io/views/map.

Silva, L.; Abe, K.; Miraglia, S., 2017. Avaliação de impacto à saúde da poluição do ar no município de Diadema, Brasil. Revista Brasileira de Ciências Ambientais, (46), 117-129. https://doi.org/10.5327/Z2176-947820170258.

Rantanen, H.; Kahila, M., 2009. The SoftGIS approach to local knowledge. Journal of Environmental Management, v. 90, (6), 1981-1990. https://doi. org/10.1016/j.jenvman.2007.08.025.

Rezende, W.S.; Alvim, A.T.B., 2016. Projeto urbano e espaço público em favelas. Revista Nacional de Gerenciamento de Cidades, v. 4, (28), 76-96. https://doi.org/10.17271/23188472.

Salinas Rebolledo, E.A.; Chiavaralloti Neto, F.; Giatti, L.L., 2018. Experiencias, beneficios y desafíos del uso de geoprocesamiento para el desarrollo de la atención primaria de salud. Revista Panamericana de Salud Publica, v. 42, e153. https://doi.org/10.26633/RPSP.2018.153.

Santos, F.N.P.; Toledo, R.F., 2020. Círculos de cultura sobre determinantes socioambientais: pesquisa-ação com agentes comunitárias de saúde de Paraisópolis, SP. Revista Gaúcha de Enfermagem, v. 41, e20190353. https://doi. org/10.1590/1983-1447.2020.20190353. 
Silva, T.L.; Soares, A.N.; Lacerda, G.A.; Mesquita, J.F.O.; Silveira, D.C., 2020. Política Nacional de Atenção Básica 2017: implicações no trabalho do Agente Comunitário de Saúde. Saúde e Debate, v. 44, (124), 58-69. http://dx.doi. org/10.1590/0103-1104202012404.

Silveira, M.; Fenner, A.L.D., 2017. Avaliação de Impactos à Saúde (AIS): análises e desafios para a Vigilância em Saúde do Brasil. Ciência \& Saúde Coletiva, v. 22, (10), 3205-3214. https://doi.org/10.1590/1413812320172210.18272017 .

Smith, K.R.; Ezatti, M., 2005. How environmental health risks change with development: the epidemiologic environmental risk transitions revisited. Annual Review of Environment and Resources, v. 30, 291-333. https://doi. org/10.1146/annurev.energy.30.050504.144424.
Sobral, A.; Freitas, C.M., 2010. Modelo de organização de indicadores para a operacionalização dos determinantes socioambientais da saúde. Saúde e Sociedade, v. 19, (1), 35-47. http://dx.doi.org/10.1590/S010412902010000100004.

Toledo, R.F.; Giatti, L.L., 2015. Challenges to participation in action research. Health Promotion International, v. 30, (1), 162-173. https://doi.org/10.1093/ heapro/dau079.

Toledo, R.F.; Matuk, T.; Coradello, M.A.; Moraes, M., 2020. Aprendizagem social e diálogo: experiência de criação de pólos de educação ambiental em dois parques municipais da cidade de São Paulo. In: Monteiro, R.A.A.; Sorrentino, M.; Jacobi, P.R. (Eds.). Diálogo e transição educadora para sociedades sustentáveis. IEE-USP, Editora na Raiz, São Paulo, pp. 197-210 (Accessed May 7, 2020) at: https://editoranaraiz.wordpress.com/2020/09/22/ livro-dialogo-e-transicao-e-educadora-para-sociedades-sustentaveis/ 